\title{
Enhancement of Black Gram Productivity through Foliar Spray of Nutrients and Growth Hormones - A Review
}

\author{
T. Ramesh*, S. Rathika, S. Sangeetha, S. Satheesh, M. Ponpradeepa and A. M. Pavithra
}

Department of Agronomy, Anbil Dharmalingam Agricultural College and Research Institute, Tamil Nadu Agricultural University, Tiruchirapalli, India

*Corresponding author

\section{Keywords}

Black gram, Foliar spray, Urea, DAP, $\mathrm{KCl}$,

Micronutrients,

Panchagavya, NAA, Salicylic acid, Pulse wonder

\section{Article Info}

Accepted:

12 November 2020 Available Online:

10 December 2020

\section{A B S T R A C T}

Black gram is an important pulse crop in India. It is a major source of dietary protein for the poor people and provides nutritional security. It is mostly grown by the small and marginal farmers under resource constraints situation particularly in rainfed and rice fallow conditions. Black gram yield is low due to various reasons includes poor management practices, various physiological, biochemical as well as inherent factors associated with the crop. Insufficient partitioning of assimilates, flower dropping and poor pod setting are mainly due to lack of nutrients during critical stages of crop growth resulted in poor yield. To improve the productivity of black gram, foliar spray of nutrients and growth hormones at reproductive stage could be followed. It would help the nutrients and hormones to reach the site of food synthesis directly, leading quick supply of food improves the performance of the crop. Many field trials confirmed that foliar spray of $2 \%$ urea, $2 \% \mathrm{DAP}, 1 \% \mathrm{KCl}$ either alone or in combinations registered significant increase in growth, yield attributes, grain yield and net return of black gram. Use of micronutrients like $0.5 \% \mathrm{FeSO}_{4}, 0.5 \% \mathrm{ZnSO}_{4}$ or $0.5 \%$ chelated micronutrients also noticed to increase the productivity. Complex fertilizers, 19:19:19 or 18:18:18 NPK at 1-2\% foliar spray found to be beneficial in black gram. Indigenous organic preparation, panchagavya foliar spray at $3 \%$ showed advantages in improving the productivity of black gram. Growth hormones like NAA and salicylic acids are used to alleviate the major physiological constraints particularly flower and fruit drop. Foliar spray of NAA 30-50 ppm and salicylic acid at 100-150 ppm found to be enough to increase the yield attributes and yield of black gram. Pulse wonder, a booster with nutrients and growth regulators developed by Department of Physiology, TNAU, Coimbatore used as a foliar spray at $1 \%$ peak flowering registered significantly higher grain yield of black gram over control.

\section{Introduction}

Black gram (Phasiolus mungo L.) is commonly known as Urad in India. It is an annual pulse crop grown mostly as rainfed or rice fallow crop. It has relatively short duration nature and enriches soil nitrogen by fixing atmospheric nitrogen. About $70 \%$ of world's black gram production comes from India. It is mainly cultivated in cereal-pulse cropping system primarily to conserve the soil nutrients and utilize the left over soil moisture 
particularly, after rice cultivation. It is $3^{\text {rd }}$ important pulse crop, was cultivated over an area of 5.44 Mha (kharif + rabi) and recorded a production of $3.56 \mathrm{Mt}$ at a productivity level of $655 \mathrm{~kg} / \mathrm{ha}$ (Anonymous, 2018). Major contributing states have been Madhya Pradesh, Rajasthan, Andhra Pradesh, Utter Pradesh, Tamil Nadu, Maharashtra, Jharkhand and Gujarat. Black gram seed contains 25$26 \%$ proteins, $60 \%$ carbohydrates, $1.5 \%$ fat, and minerals combination, amino acid, and essential vitamins etc. The yield of black gram is low due to various reasons includes poor management practices, various physiological, biochemical as well as inherent factors associated with the crop. Insufficient partitioning of assimilates, flower dropping and poor pod setting are mainly due to lack of nutrients during critical stages of crop growth resulted in poor yield. Fertilizer application is an important practice to increase the yield of black gram. Soil application of nutrients is often not enough to meet the growing crop demand particularly in short duration crop like black gram, as it is basically indeterminate in habit of flowering and fruiting, there is a continuous competition for available assimilates between vegetative and reproductive sinks throughout the growth period. Under rice fallow situation, black gram is sown prior to harvest of rice and there is no possibility of basal application of fertilizer. Under these circumstances foliar application of nutrients would be more appropriate, efficient and economical than the soil application (Balusamy and Meyyazhagan, 2000).

Application of fertilizers on leaves of growing plants with suitable concentrations is termed as foliar application. In many cases aerial spray of nutrients is preferred and gives quicker and better results than the soil application (Jamal et al., 2006). Foliar application of nutrient and growth regulator at pre flowering and flowering stage was seen on reduction in flower drop percentage in black gram (Ganapathy et al., 2008). Foliar nutrition is recognized as an important method of fertilization, since foliar nutrients usually penetrate the leaf cuticle or stomata and enters the cells facilitating easy and rapid utilization of nutrients. It has an advantage advantage of quick and efficient utilization of nutrients, elimination of losses through leaching, fixation and regulating the uptake of nutrients by plant (Manonmani and Srimathi, 2009). Since foliar nutrients usually penetrate the leaf cuticle or stomata and enters the cells facilitating easy and rapid utilization of nutrients. Foliar application of growth regulating chemicals at critical stages of the crop is one of the latest trends in agriculture which play a significant role in improving the physiology and productive potential of the crop. Growth regulating substances/growth regulators are known to influence a wide array of physiological parameters viz., alteration of plant architecture, assimilate partitioning, promotion of photosynthesis, uptake of nutrients (mineral ions), enhancing nitrogen metabolism, promotion of flowering, uniform pod formation, increased mobilization of assimilates to defined sinks, induction of synchrony in flowering and delayed senescence of leaves and improved seed quality (Sharma et al., 2013). The influence of various nutrients and growth hormones includes urea, DAP, complex fertilizers, panchagavya, pulse wonder, NAA and Salicylic acid as foliar spray on growth and yield black gram are reviewed in this paper.

\section{Urea}

Urea is the most concentrated solid nitrogenous fertilizer, containing $46 \%$ nitrogen. It is a white crystalline substance readily soluble in water. It improves the vegetative growth, leaf chlorophyll content and leaf area index and yield of crops. Pulses 
crops particularly black gram response well to foliar spray of urea. Many findings are confirmed the advantages of urea spray in black gram at 1 to $2 \%$ concentration. Foliar application of $\mathrm{N}$ may solve slow growth, nodule senescence and low seed yield of pulse (Latha and Nadanasababady, 2003). Sritharan et al., (2005) reported that foliar spray of $2 \%$ urea recorded higher grain yield of $955 \mathrm{~kg} / \mathrm{ha}$ in black gram. Whereas, Senthil Kumar et al., (2008) found that foliar of $1 \%$ urea at floral initiation and 15 days after flowering in black gram registered higher growth, yield parameters and yield. Similarly, Verma et al., (2011) found that an increment in grain yield was 27.4 to $31.0 \%$ due to foliar spray of $2 \%$ urea solution at 40 days after sowing in different black gram varieties. Significant increase in the NPK content of the leaf was noticed in black gram due to basal application of nitrogen $25 \mathrm{~kg} / \mathrm{ha}$ along with foliar spray of urea $2 \%$ and $0.1 \mathrm{ppm}$ brassinolide. (Surendar et al., 2013). Das and Jana (2015) reported that application of $2 \%$ urea significantly increased the seed yield of black gram over basal dose of fertilizer application.

Foliar spray of $2 \%$ urea significantly improved the growth parameters, physiological parameters like chlorophyll content, soluble protein and nitrate reeducates activity in black gram and ultimately increased the grain yield $(900 \mathrm{~kg} / \mathrm{ha})$ to the tune of $20 \%$ over control (Sritharan et al.,2015). Similarly, spray of $2.0 \%$ urea produced significantly higher growth indices viz., RGR, CGR and LAD at all growth stages, growth and yield parameters and grain yield of black gram than control (Vijay Singh et al., 2017)

\section{DAP}

Di ammonium phosphate (DAP) is the world's most widely used phosphorus fertilizer. It is an excellent source of phosphorus $(\mathrm{P})$ and nitrogen $(\mathrm{N})$ for plants. Foliar spray of DAP increased the photosynthetic ability which resulted in increased accumulation of dry matter and also efficient portioning of photosynthates towards sink (Ganapathy et al., 2008). Foliar spray of DAP met constant requirement of nitrogen and phosphorus at reproductive stage of the crop and variation in the yield components like number of pods / plant, number of seeds /pod pod length and test weight, which had direct influence on the grain yield (Mondal et al., 2011). Application of DAP 2\% spray at flowering and 15 days later recorded higher grain yield (916 kg/ha) and net return (Rs. 23313 /ha) in black gram (Deepak Kumar et al., (2018).

\section{$\mathrm{DAP}+\mathrm{KCl}$}

Combination of DAP and $\mathrm{KCl}$ spray supplies all the macro nutrients at critical stages improved the photosynthetic activity and productivity of black gram. Under rice fallow condition, basal application of fertilizer $\mathrm{N}$ and P2O5 @ 12.5:25 kg ha-1 just before the harvesting of preceding rice crop along with foliar spray of $2 \% \mathrm{DAP}+1 \% \mathrm{KCl}$ twice at flowering and pod filling stages was significant for NPK uptake, yield attributes and yield (Geetha and Velayutham, 2016). Similarly, Ramesh et al., (2016) also reported that application of DAP $50 \mathrm{~kg} /$ ha to preceding rice in last irrigation and foliar spray of $2 \%$ $\mathrm{DAP}+1 \% \mathrm{KCl}$ at 30 and 45 days after sowing recorded higher plant height, number of pods per plant, grain yield $\left(639 \mathrm{~kg} \mathrm{ha}^{-1}\right)$, net returns (Rs.22290 ha ${ }^{-1}$ ) additional income (Rs. $7563 \mathrm{ha}^{-1}$ ) and benefit cost ratio of 3.56 in Cauvery Delta Zone, Tamil Nadu. Significant increase was recorded in plant height, dry matter production, and number of pods/plant, number of seeds/plant, test grain weight and grain yield with foliar spray of $2 \%$ $\mathrm{DAP}+1 \% \mathrm{KCl}$ at flowering and 15 days later and it is considered as the viable nutrient 
management package to the pulses for getting higher income through higher productivity (Uma Maheswari and Karthik, 2017).

\section{DAP + Growth hormones +Micronutrients}

Foliar application of 2\% DAP + NAA 40 ppm + B $0.2 \%+$ Mo $0.05 \%$ at 30 DAS significantly increased the height and dry weight of plants, number of pods/plant, seeds/pod, test weight, grain yield and haulm yield over the control (Dixit and Elamathi, 2007). Foliar application of DAP $2 \%+$ NAA $40 \mathrm{ppm}+\mathrm{ZnSO}_{4} 0.5 \%+$ $\mathrm{FeSO}_{4} 1 \%$ twice at pre flowering, flowering stage recorded significantly higher reproductive efficiency and grain yield in rice fallow black gram (Ganapathy et al., 2008). Khodadad and Mostafavi (2012) reported that use of micronutrients like Zinc ( $\mathrm{Zn}$ ), Iron $(\mathrm{Fe}), \quad$ Boron (B), Manganese (Mn), Molybdenum (Mo), Copper $(\mathrm{Cu})$, Cobalt $(\mathrm{Co})$ and Nickel (Ni) has now become a common practice to increase crop yield especially under adverse environmental conditions in pulses. Foliar spray of micronutrients improve flowering, pollen production capacity, pollen viability, stigma receptivity and pollen-stigma interaction and also increased the yield parameters like numbers, size and weight of pod and seeds (Nalini Pandy and Bhavana Gupta, 2012). Foliar spray treatment with the aqueous solution of nutrients (2\% DAP, $1 \%$ $\mathrm{K}, 2 \% \mathrm{~N}$ and $200 \mathrm{ppm} \mathrm{NAA}$, w/v) was done to the $22^{\text {nd }}$ and $30^{\text {th }}$ day old black gram seedlings and also observed that growth, yield and grain yield was significantly increased with foliar application of nutrients (Doss et al., 2013). Application of recommended dose of fertilizer (RDF) followed by foliar spray of $2 \% \mathrm{DAP}+40 \mathrm{ppm} \mathrm{NAA}+0.5 \%$ chelated micronutrient recorded higher growth components such as plant height, number of branches, leaf area index, leaf area duration, total dry matter production, number of pods per plant, higher grain yield (1298 $\mathrm{kg} / \mathrm{ha}$ ), net returns and $\mathrm{B}: \mathrm{C}$ ratio in black gram (Shashikumar et al., 2013). Significantly, higher plant height, dry matter production, number of pods per plant, seeds per pod, test weight, grain yield and haulm yield over the control under foliar application of DAP $2 \%+0.50 \% \mathrm{ZnSO} 4+0.50 \% \mathrm{FeSO} 4$ $+0.10 \%$ boric acid $+0.05 \%$ sodium molybdate $+0.05 \%$ cobalt chloride (Suhathiya and Ravichandran, 2018).

\section{Complex fertilizers}

Complex fertilizers supply all three primary nutrients (NPK). Foliar application of 3\% NPK (19-19-19) recorded higher seed yield of black gram (Das and Jana, 2015). Application of 19:19:19 (NPK) 2\% spray at flowering stage recorded higher grain yield $(870 \mathrm{~kg} / \mathrm{ha})$ and net return (Rs. 20108 /ha), which was at par with treatment application of DAP 2\% spray at flowering and 15 days later (Deepak Kumar et al., (2018). Foliar application of 18:18:18 NPK 2\% spray at flowering and 15 days after flowering recorded higher grain yield (795 kg/ha), net returns (Rs.27288/ha) and benefit cost ratio of 1:2.1 (Basant Kumar et al.,2020).

\section{Panchagavya}

Panchagavya, an organic product has potential to play the role in promoting growth and providing immunity in plant system. The use of fermented cow dung, urine, milk fat, curd and milk with the name of Panchagavya is getting adaptive popularity in Indian agriculture. Increased plant height may be due to increase in protein synthesis and growth regulators such as IAA and GA3, in panchagavya may enhanced the cell division, cell multiplication and cell enlargement which favours increased inter nodal length (Sanjutha et al., 2008). Panchagavya supplies of all micro and macronutrients and growth enzymes which favoured rapid cell division and multiplication. Presence of growth 
promoting substances like IAA, GA3 and cytokinin and other mineral nutrients which favours translocation of more photoassimilates to reproductive parts thereby induces early flowering (Ramaswamy and Vijaykumar, 2009). Foliar spray of 3\% panchagavya at $15^{\text {th }}, 25^{\text {th }}, 35^{\text {th }}$ and $45^{\text {th }}$ days interval period recorded significantly higher growth and yield black gram than control (Suresh Kumar et al., 2011). Cultivation of rice fallow black gram with seed soaking $3 \%$ panchagavya along with foliar spray of 3\% panchagavya twice (30 and 45 DAS) registered higher grain and haulm yield under Cauvery delta region of Tamil Nadu (Ramesh et al., 2013). Foliar application of panchagavya $4 \%$ recorded significantly maximum dry matter production, leaf area index, number of pods plant ${ }^{-1}$, number of seeds, test weight, seed yield $(801 \mathrm{~kg} / \mathrm{ha})$ and economics over other treatments (Gopal Lal et al., 2017). Gunasekar et al., (2018) reported that panchagavya 3\% foliar spray recorded higher plant height, days to $1^{\text {st }}$ flowering, days to $50 \%$ flowering, number of leaves per plant, number of branches per plant, number of pods per plant, pod length, number of seeds per pod, seed yield per plant, seed yield per plot, 100 seed weight and the resultant seed quality.

\section{NAA}

NAA is a synthetic plant hormone in the auxin family. It used as a growth regulator to increases flower production, reduce flower drop and increase grain yield in pulses. Foliar application of NAA promoting the apical dominance, cell elongation and shoot development. Application of NAA at $40 \mathrm{ppm}$ was more effective and significantly increased the number of seeds per plant, number of pods per plant, pod weight, pod wall dry weight, pod length and grain yield in black gram (Prabhu, 2000). Application of 50 ppm NAA $+6 \%$ cow urine at 25, 40 and 55 DAS, registered higher leaf chlorophyll and seed protein content (Ingale, 2007). Foliar application of NAA $40 \mathrm{ppm}$ at pre-flowering stage increased the plant height, more number of branches, higher leaf area index and leaf area duration in black gram (Jeyakumar et al., 2008). Similarly, foliar spray of NAA30 ppm improved the dry matter production, increased the number of pods per plant, number of grains per pod and grain yield in black gram (Kadam et al., 2009). Application of urea at $2 \%$ and NAA at 40 ppm was proved to be the best treatment for obtaining higher plant height, no. of branches, root nodule, plant dry weight and higher protein content were obtained in black gram variety T-9 (Improved) (Esther and Gautam, 2020).

\section{Salicylic acid}

Salicylic acid (SA) is a phenolic phytohormone found in plants. It improves the plant growth and development, photosynthesis, transpiration, ion uptake and transport and increase the grain yield of pulses. It induced more flowering at 10 and 100 ppm levels (Anandhi and Ramanujan, 1997). Functionally, it induces flower production and promotes disease resistance. It is ortho-hydroxybenzoic acid and is a secondary metabolite acting as analogous of growth regulating substances. Foliar application of salicylic acid exerted a significant effect on plant growth metabolism when applied at physiological concentration, and thus acted as one of the plant growth regulating substances (Kalarani, et al; 2002). Jeyakumar et al., (2008) reported that application of $125 \mathrm{ppm}$ salicylic acid to black gram plants increased seed yield. Foliar spray of nutrients mixture with salicylic acid 100 ppm at 20, 30 and 40 DAS increased the plant physiological parameters includes leaf area index, leaf area duration, specific leaf weight, total dry matter accumulation and ultimately maximize 26 per cent more grain yield in 
black gram (Amutha et al., 2012). Application of $150 \mathrm{ppm}$ salicylic acid along with $500 \mathrm{ppm}$ zinc sulphate produced significantly higher seed yield of black gram (Ali et al., 2013). Application of SA at $150 \mathrm{ppm}$ as foliar spray at 25, 40 and 55 DAS improved the physiological efficiency of crop and resulted in better growth and yield of black gram cv. NDU-1 (Manjri et al., 2018). Foliar application of $100 \mathrm{ppm}$ SA increased the grain yield up to $21.4 \%$ in black gram under salinity condition over control (Sivakumar et al., 2018).

\section{TNAU Pulse Wonder}

TNAU Pulse wonder is a booster with nutrients and growth regulators, especially for pulse crop was developed by Department of Physiology, TNAU, Coimbatore. It contains combination of nutrients and growth regulators which plays a major role in growth, development and metabolism of black gram (Marimuthu and Surendran, 2015). It is recommended at $1 \%$ foliar spray at peak flowering stage of pulses. It reduces flower shedding, increases yield up to $20 \%$ and increases drought tolerance in pulse crops. Application of $100 \%$ recommended dose of NPK along with foliar spray of DAP $2 \%$ + TNAU pulse wonder $5.0 \mathrm{~kg} \mathrm{ha}^{-1}$ produced significantly higher growth and yield parameters, grain yield (1162 $\mathrm{kg} \mathrm{ha}^{-1}$ ) and benefit cost ratio (2.98) over the NPK alone in black gram (Marimuthu and Surendar, 2015). Similarly, foliar spray of TNAU pulse wonder at $1 \%$ recorded higher plant height, leaf area index and grain yield in black gram (Sachin et al, 2019). foliar spray of TNAU Pulse wonder $1.125 \%$ followed by foliar spray of Polyfeed $1 \%$ + NAA 40 ppm was recommended to get profitably higher yield besides improving the quality of Black gram with a B: C ratio of 2.95. (Arun Raj et al., 2018). Devaraju and Senthilvel (2018) also reported that application of pulse wonder @ $\mathrm{kg} / \mathrm{ha}$ at flowering and 15 days after $1^{\text {st }}$ spray was significantly increased the number of pods per plant, number of grains per pod, grain yield $\left(870 \mathrm{~kg} \mathrm{ha}^{-1}\right)$, net returns and benefit cost ratio of black gram. Under salinity condition, foliar application of $1 \%$ TNAU Pulse Wonder at 20 and 40 days after sowing increased the root volume up to $40 \%$ in black gram (Sivakumar et al., 2018). Foliar application of pulse wonder $1 \%$ on $50 \%$ flowering stage recorded higher values of growth components (viz., plant height, leaf area index, dry matter production, number of branches per plant), yield attributes (viz., number of branches, number of pods plant ${ }^{-1}$, number of seeds pod ${ }^{-}$ ${ }^{1}$ ), seed and haulm yield of black gram (Balaji et al., 2019). TNAU pulse wonder improved the source-sink relationship compared to other treatments with enhanced biometric, growth parameters and yield of black gram (Sachin et al., 2019). Foliar application of $1 \%$ pulse wonder spray on 25 DAS followed by $0.5 \%$ 19:19:19 NPK spray on 45 DAS recorded higher growth attributes viz., plant height, LAI, nodule number and nodule biomass and DMP (Karthikeyan et al., 2020)

In conclusion the productivity of black gram is not sufficient to meet the domestic demand of the growing Indian population. Thus, it is highly essential to improve the productivity of black gram by proper agronomic practices. Foliar feeding of nutrients and growth hormones is viable approach to exploit the genetic potential of the black gram. Soil application of nutrients is often not enough to meet the growing crop demand particularly in short duration crop like black gram. Many research findings have been confirmed the benefits of foliar nutrition at flowering and 15 days after on the grain yield of black gram. With reference to macro nutrients, foliar spray of $2 \%$ urea, $2 \%$ DAP, $1 \% \mathrm{KCl}$ either alone or in combinations registered significant increase in growth, yield attributes, grain 
yield and net return of black gram. Use of micronutrients like $0.5 \% \mathrm{FeSO}_{4}, 0.5 \% \mathrm{ZnSO}_{4}$ or $0.5 \%$ chelated micronutrients also noticed to increase the productivity. Complex fertilizers, 19:19:19 or 18:18:18 NPK at 1-2 $\%$ foliar spray found to be beneficial in black gram. Indigenous organic preparation, panchagavya foliar spray at 3\% improved the productivity of black gram. Growth hormones like NAA and salicylic acids are used to alleviate the major physiological constraints particularly flower and fruit drop. Foliar spray of NAA 30-50 ppm and salicylic acid at 100$150 \mathrm{ppm}$ found to be enough to increase the yield attributes and yield of black gram. Recently, many experiments confirmed the benefits of pulse wonder, a booster with nutrients and growth regulators developed by Department of Physiology, TNAU, Coimbatore at $1 \%$ peak flowering registered significantly higher grain yield of black gram over control. Thus, from this review paper, it could be concluded that foliar spray twice at reproductive stage either with nutrients or growth hormones or combination of both considered as important strategy to improve the productivity and profitability of black gram.

\section{References}

Ali. E.A., and Adel M. Mohamoud. 2013. Effect of Foliar Spray by Different Salicylic Acid and Zinc Concentrations on Seed Yield and Yield Components of Mungbean in Sandy Soil. Asian journal of crop science 5(1): 33- 40.

Amutha R., S. Nithila and Sivakumar, T. 2012. Management of source limitation by foliar spray of nutrients and growth regulators in Black gram, International Journal of Plant Sciences.7 (1):65-68.

Anandhi, S.T., and Ramanujam, M. P. 1997. Effect of foliar spray on black gramcultivars. Indian J. Plant Physiol., 2: 138-141.
Anonymous, 2018. Pulses revolution from food to nutritional security. https://farmer.gov.in/SucessReport2018 -19.pdf

Arun Raj M., P. Sathya and Vignesh, S. 2018. Effect of Foliar Nutrition for Maximizing the Productivity of Black Gram (Vigna mungo L.) International Journal of Science, Environment and Technology. 7(6): $2026-2032$.

Balaji, P., S.R Vinod Kumar, G. Srinivasan and Kancheti Mrunalini. 2019. Effect of foliar nutrition on yield maximization strategies for irrigated black gram cv. ADT 3. Journal of Pharmacognosy and Phytochemistry. 2019; 8(3): 2884-2886

Balusamy, M., and Meyyazhagan, N. 2000. Foliar nutrition to pulse crop. Training manual on recent advances in pulses production technology, CASA, Tamil Nadu Agricultural University, pp 113115.

Basant Kumar M., R.P. Singh, Megha Dubey, Usha Waskle and Vinod Birla. 2020. Effect of foliar application of nutrients on growth and yield attributing characters of black gram. Int.J.Curr.Microbiol.App.Sci. $\quad$ 9(02): 419-428.

Das, S. K., and Jana, K. 2015. Effect of foliar spray of water soluble fertilizer at pre flowering stage on yield of pulses. Agric. Sci. Digest. 35(4): 275-279.

Deepak Kumar, D., R.P. Singh, J. Somasundaram, Vidya Simaiya and Shweta Jamra. 2018. Effect of foliar application of nutrients on growth and development of black gram (Vigna mungo (L.) Hepper) under rainfed Vertisols of Central India. International Journal of Chemical Studies. 6(1): 609613

Devaraju, B., and Sethivel. T. 2018. Effect of foliar application of different source of nutrients in growth and yield of black gram under Irrigated condition. 
Int.J.Curr.Microbiol.App.Sci. $\quad 7(1)$ : 3205-3109.

Dixit, P.M., S. Elamathi, KZ. Kishor, Neeta, C. 2008. Effect of foliar application of nutrients and NAA in mungbean. $J$ Food Legume. 21: 277-278.

Doss, A., Anand, S.P. and Keerthiga, M. 2013. Effect of foliar application of DAP, Potash and NAA on growth yield and some biochemical constituents of Vigna mungo (L.) J. Agric.Res. 2(7): 206-208.

Esther, D., and Gautam, G. 2020. Effect of foliar nutrition and plant growth regulators on growth of Black gram (Vigna mungo L.). Journal of Pharmacognosy and Phytochemistry. 9(3): 1754-1756

Ganapathy, M., G. Baradhan and Ramesh, N. 2008. Effect of foliar nutrition on reproductive efficiency and grain yield of rice fallow pulses. Legume Res., 31(2):142-144.

Geetha, P., and Velayutham, A. 2016. Yield attributes, yield and uptake of nutrients as influenced by basal and foliar application of nutrients on rice fallow black gram. Indian J. Agric. Res., 50 (2): $122-125$

Gopal Lal Choudhary, S.K Sharma, Sanju Choudhary, Kendra Pal Singh, M.K Kaushik and Bazaya, B.R. 2017. Effect of panchagavya on quality, nutrient content and nutrient uptake of organic black gram [Vigna mungo (L.)]. Journal of Pharmacognosy and Phytochemistry. 6(5): 1572-1575.

Gunasekar, J., K. Swetha Reddy, G. Poovizhi Sindhu, S. Anand, G. Kalaiyarasi, M. Anbarasu and Dharmaraj, K. 2018. Effect of Leaf Extracts and Panchagavya Foliar Spray on Plant Characters, Yield and Resultant Seed Quality of Black gram [Vigna mungo (L.)] cv. $\quad \mathrm{CO} \quad 6$. Int.J.Curr.Microbiol.App.Sci.7(2):3205-
3214.

Ingle, S. R. 2007. Physiological responses of black gram to foliar sprays of cow urine and NAA. M. Sc. (Agri.) thesis (unpub.) submitted to Dr. P. D. K. V. Akola

Jamal, Z., Muhammad Hamayun, Nadeem Ahmad and Fayyaz Chaudhary, M. 2006. Effects of Soil and Foliar Application of Different Concentrations of NPK and Foliar Application of $\left(\mathrm{NH}_{4}\right)_{2} \mathrm{SO}_{4}$ on Different Yield Parameters in Wheat. Journal of Agronomy, 5: 251-256

Jeyakumar, P., G. Velu, C. Rajendran, R. Amutha, MAJR. Savery, Chidambaram S. 2008. Varied responses of black gram (Vigna mungo) to certain foliar applied chemicals and plant growth regulators. Legume Res. 31(2):110-113.

Kadam, G.R., S.V. Kalyankar, Borgaonkar SB, Kadam BP. 2009. Effect of sowing dates and NAA application on growth, development and yield in black gram (Vigna mungo L.). International Journal of Plant Sciences. 3(2):567- 569.

Kalarani, M.K., Thangaraj, M., Sivakumar, R., Anbumani, B., Suresh, T. and Arumugan, K. 2001. Role of plant growth regulators in rice production: A review. Agric. Rev., 22: 33-40.

Karthikeyan,A, J. Vanathi, S. Babu and C. Ravikumar. 2020. Studies on the effect of foliar application of organic and inorganic nutrients on the phenotypic enhancement of black gram cv.Vamban6. Plant Archives 20(2):1161-1164

Khodadad and Mostafavi. 2012. Grain yield and yield components of soybean upon application of different micronutrient foliar fertilizer at different growth stages. Int. J Agric Res., 2(4):389-394.

Latha, M.R. and T. Nadanassababady. 2003. Foliar nutrition in crops. Agric. Rev., 24(3): 229-234

Manjri Singh A, Gupta SD, Bahadur R \& Singh AK. 2018. Responses of Black 
gram (Vigna mungo) to Foliar Applied Plant Growth Regulators, Int.J.Curr.Microbiol.App.Sci.,7:40584064.

Manonmani, V. and Srimathi, P. 2009. Influence of mother crop nutrition on seed and quality of black gram. Madras Agric. J., 96:125-128.

Marimuthu S, Surendran U. 2015. Effect of nutrients and plant growth regulators on growth and yield of black gram in sandy loam soils of Cauvery new delta zone. Cogent Food and Agric., 2015; $1: 1010415$

Mondal, M.M.A., M.A. Rahman, M.B. Akter and M.S.A. Fakir. 2011. Effect of foliar application of nitrogen and micronutrients on growth and yield of mungbean. Legume Res., 34(3): 166171.

Sritharan N, Anitha Aravazhi, Mallika Vanangamudi. 2005. Study the morphological physiological and biochemical effects of foliar spray of nutrients and plant growth regulators on yield and productivity of black gram. Madras Agricultural Journal. 92(46):301-307.

Nalini Pandey and Bhavana Gupta. 2012. Improving seed yield of black gram (Vigna mungo L. Vary: DPU-88-31) through foliar fertilization of zinc during the reproductive phase. J Plant. Nutr. 35(11):1683-1692.

Prabhu.D.2000. Influence of growth regulators and micronutrients in black gram, M.Sc (Ag) Thesis. University of agricultural Science, Bangalore.

Suresh Kumar R., P. Ganesh, K. Tharmaraj and P.Saranraj. 2011. Growth and development of black gram (Vigna mungo) under foliar application of Panchagavya as organic source of nutrient. Curr. Bot. 2(3):9-11.

Ramaswamy, V. and Vijaykumar, A. 2009. Effect of organic foliar application on seed yield and quality in senna. Seed Res., 37(1\&2): 48-52.

Ramesh, S., Sudhakar, P. and Elankavi S. 2013. Effect of foliar nutrition on growth, yield attributes and yield of rice fallow black gram [Vigna mungo]. International Journal of Development Research. 3(2): 5-7.

Ramesh, T., V. Ravi, T. Parthipan and Rathika, S. 2016. Productivity enhancement in rice fallow black gram through refinement of nutrient management. Legume Res. 39(1): 106109.

Sachin, A.S., T. Sivakumar, K. KrishnaSurendar, Senthivelu, M. 2019. Influence of plant growth regulators and nutrients on biometric, growth and yield attributes in Black gram (Vigna mungo L.). Journal of Agriculture and Ecology. 1(7): 55-63.

Sanjutha, S., S. Subramanian, I. Rani, and Maheswari. 2008. Integrated nutrient management in Andrographis paniculata. Res. J. Agric. Biol. Sci., 4(2): 141-145.

Senthil Kumar, G., P. Muthukrishnan, S.Ramasamy and K. K. Chandragiri,. 2008. Effect of organic and inorganic foliar spray on growth and yield of black gram. Madras Agricultural Journal. 95: 57-60.

Sharma, P., V. Sardana, and Sukhvinder S. K. 2013. Dry matter partitioning and source sink relationship as influenced by foliar sprays in groundnut. The Bioscan, 8: 1171-1176.

Shashikumar, R., Basavarajappa, S.R., Salakinkop, Manjunatha Hebbar, Basavarajappa MP, Patil HY. 2013. Influence of foliar nutrition on performance of Black gram (Vigna mungo L.), nutrient uptake and economics Under dry land ecosystems. Legume Research. 36(5):422-428. 
Sivakumar, R., Jaya Priya and Nithila S. 2018. Impact of Plant Growth Regulators and Nutrient Consortium on Growth, Superoxide Dismutase, $\mathrm{Na}+\mathrm{K}+$ ratio and Yield of Black gram under Salinity Stress. International Journal of Agriculture, Environment and Biotechnology. 11(5): 791-798.

Sritharan, N., M. Rajavel and Senthilkumar R. 2015. Physiological approaches: Yield improvement in black gram. Legume Res. 38(1): 91-95.

Suhathiya, K., and Ravichandran, M. 2018. Effect of foliar application of DAP and micronutrients on crop growth attributes and yield of rice fallow black gram (Vigna mungo L.). Int. J. Adv. Res. Biol. Sci. 5(4): 72- 76.

Surendar, K., S. Vincent, Mallika Vanagamudi, Vijayaraghavan, H. 2013. Plant growth regulators and nitrogen responses on improving nutrient content of black gram (Vigna mungo L.), Plant Gene and Trait. 4(12): 66-69

Uma Maheswari, M., and Karthik, A. 2017. Effect of foliar nutrition on growth, yield attributes and seed yield of pulse crops. Adv Crop Sci Tech. 5(3): 278

Verma C.K., R.B. Yadav, B.P. Dhyani and Sandeep Singh Tomar. 2011. Effect of seed rates and foliar spray of urea on performance of black gram (Vigna mungo) varieties. Indian Journal of Agricultural Sciences. 81(9):881-882

Vijaysingh Thakur, R.P., Patil, J.R. Patil, T.C. Suma and Umesh M.R. 2017. Influence of foliar nutrition on growth and yield of black gram under rainfed condition. Journal of Pharmacognosy and Phytochemistry. 6(6): 33-37

\section{How to cite this article:}

Ramesh, T., S. Rathika, S. Sangeetha, S. Satheesh, M. Ponpradeepa and Pavithra, A. M. 2020. Enhancement of Black Gram Productivity through Foliar Spray of Nutrients and Growth Hormones - A Review. Int.J.Curr.Microbiol.App.Sci. 9(12): 1594-1603.

doi: https://doi.org/10.20546/ijcmas.2020.912.189 